\title{
DIDYMODON ANSERINOCAPITATUS, NEW TO RUSSIA FROM THE YENISEY RIVER, SOUTH SIBERIA
}

\section{DIDYMODON ANSERINOCAPITATUS - НОВЫЙ ВИД ДЛЯ РОССИИ, НАЙДЕННЫЙ НА ЕНИСЕЕ В ЮЖНОЙ СИБИРИ}

\author{
T. N. OTNYUKOVA ${ }^{1} \&$ R. H. ZANDER ${ }^{2}$ \\ Т. Н. ОТНЮКОВА и Р. Г. ЦАНДЕР
}

Abstract

The rare moss, Didymodon anserinocapitatus (X.-j. Li) Zand., is reported for the South Siberia, Russia, as the eighth known locality in the world. This species has been described from Tibet in China and has been recently found in New Mexico and Colorado of the U.S.A.

Резюме

Редкий мох Didymodon anserinocapitatus (X.-j. Li) Zand. приводится впервые для Южной Сибири и России в целом. Этот вид был описан из Тибета (Китай) и недавно найден также США, в штатах Колорадо и Нью Мексико.

The first author has found an interesting pottiaceous moss from Yenisey River, South Siberia, Russia and at first identifyed it as Didymodon johansenii (Williams) Crum (Otnyukova, 1995). However the second author re-identified these specimens as D. anserinocapitatus (X.-j. Li) Zand. The latter species has been described from Xizang (Tibet) in China, and subsequently found in four more localities in the same province, between Lhasa and Metuo regions (Gao, 1996). Also two specimens of $D$. anserinocapitatus has been discovered among collections from the foothills of the Rocky Mountains in the U.S.A. (Zander \& Weber, 1997), in the states of Colorado and New Mexico.

In South Siberia Didymodon anserinocapitatus has been collected twice in the same locality: "Vicinity of Krasnoyarsk City, Yenisey River left bank, $250 \mathrm{~m}$ elev., on sandstones with alluvial depositions, T. Otnyukova, 30.VI.1995 (BUF, KRF) and 6.VII.1996 (KRF).

This territory is on the boundary of three geomorphological zones: the northeastern spurs of the East Sayan Upland (Altai-Sayan Mountains Region), the south edge of the West Siberian Lowland, and the southwestern edge of the Middle Siberian Plateau. The left bank of Yeni- sey River has forest-steppe vegetation and steep slopes to the river are covered by steppes. Didymodon anserinocapitatus grows on steppe slope, with Syntrichia ruralis (Hedw.) Web.et Mohr, Grimmia tergestina Tomm. ex B. S. G., Jaffueliobryum latifolium Lindb. et Arnell, Leucodon sciuroides (Hedw.) Schwaegr., Homomallium incurvatum (Brid.) Loeske.

Didymodon anserinocapitatus (X.-j. Li) Zand., Bull. Buffalo Soc. Nat. Sci. 32: 162. 1993. Barbula anserinocapitata X.-j. Li, Acta Bot. Yunnan. 3: 103. 1981.

Isotype: "Tibet, Nan Xian, Zang Mu 1704” NY!

Plant green to reddish green. Stems to $1.5 \mathrm{~cm}$ long, central strand present, strong, sclerodermis distinct, hyalodermis absent, axillary hairs 3-4 cells long, the basal most thicker-walled. Stem leaves erect-appressed when dry, spreading when moist, monomorphic, lanceolate, adaxially weakly concave across leaf, 0.7-1.1 mm long lacking tip to $2.2 \mathrm{~mm}$ long entire, base short-sheating to long-ovate or weakly differentiated in shape, margins recurved at midleaf, entire,apex abruptly thickened,long-elli ptical to ovate, of many thick-walled cells, usually deciduous and absent in mature leaves; costa excurrent, little widened or tapering at midleaf but swollen in excurrency, adaxial costal cells quadrate, 4-6 cells wide at

\footnotetext{
1 - V. N. Sukachev's Institute for Forest Research, Siberian Branch of Russian Academy of Sciences, Akademgorodok, Krasnoyarsk 660036 Russia - Россия 660036 Красноярск, Академгородок, Институт леса Сибирского отделения Российской Академии Наук

2 - Buffalo Museum of Science, 1020 Humboldt Parkway, Buffalo, NY 14211, U.S.A.
} 


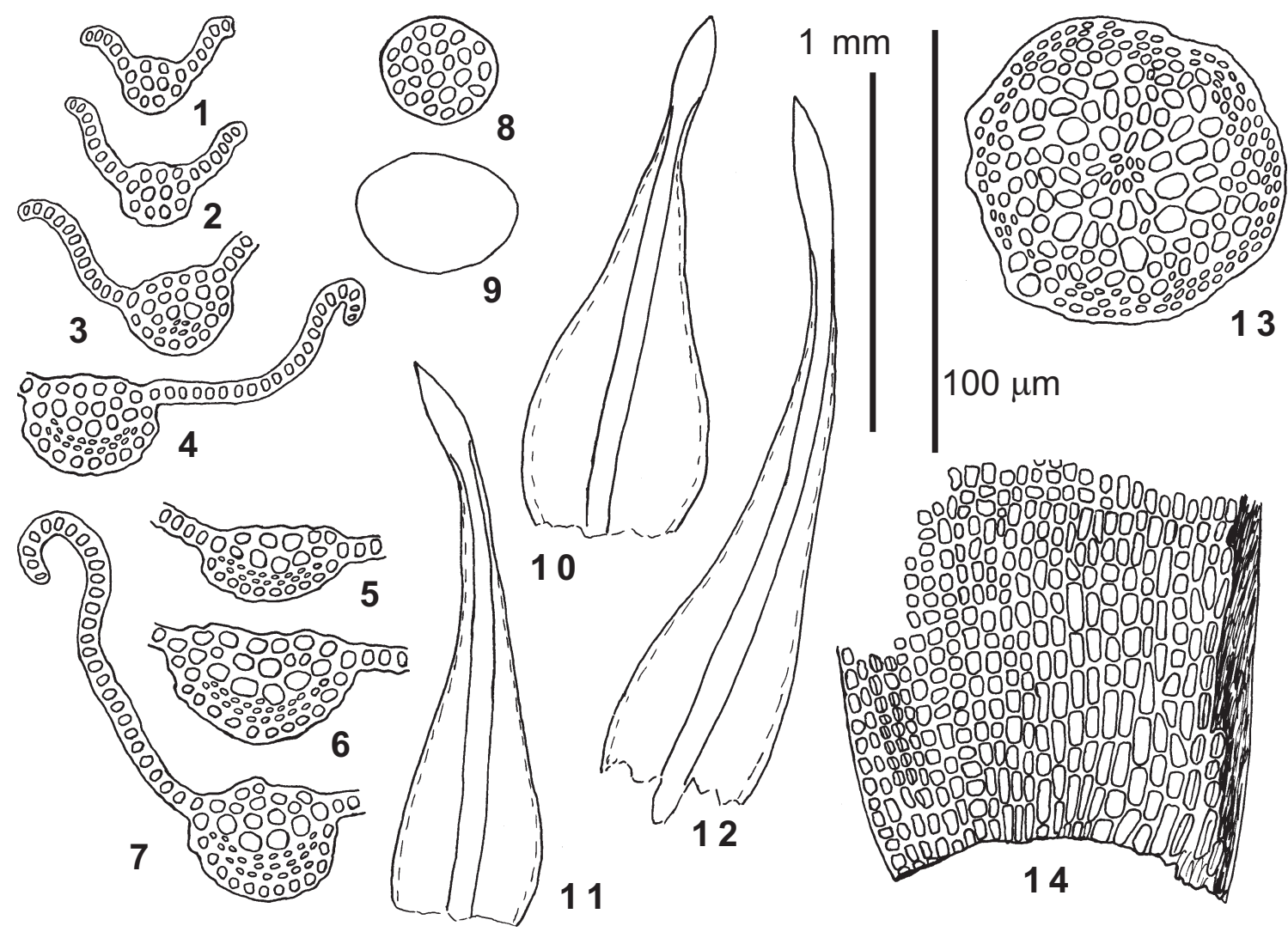

Fig. 1. Didymodon anserinocapitatus (X.-j. Li) Zand., from Siberian collection: 1-7 - leaf cross sections; 8 - cross section of propagulum in lower part; 9 - outline of propagulum in widest part; 10-12 - leaves; 13 - stem cross section; 14 - cells of leaf base. Scale bars: $1 \mathrm{~mm}$ - for 1-9, 13-14; $100 \mu \mathrm{m}$ - for 10-12.

midleaf, epidermis present on both sides, guide cells in 2 layers, dorsal stereid band weak, ventral band absent or weak, hydroid strand sometimes present; basal laminal cells differentiated medially, walls thin; upper laminal cells 8-10 mm wide, 1:1, papillae essentially absent, lumens angular, walls thin, weakly, convex on both sides, unistratose except in deciduous apex; basal cells quadrate to rectangular. Sexual features and sporophyte unknown. Upper lamina $\mathrm{KOH}$ color reaction reddish orange.

The above diagnosis was based on collections from different areas. The Siberian specimens (illustrated in Fig. 1) are small in size, 0.7-1.0 cm long, dark, brown-green to reddish-brown, turfs loose, stems erect, single or branching at the base. The leaf's apical propagulum is usually widest below the middle as in the Tibetan material, but unlike the New World material which has generally short-elliptical propagula.

Didymodon johansenii is similar in having swollen, deciduous apex (see Savicz-Ljubitzkaya
\& Smirnova, 1961; Abramov \& Abramova, 1983). However it differs in upper laminal cells larger, $13-15 \mu \mathrm{m}$ wide, and guide cells in only a single layer, whereas in D. anserinocapitatus upper cells 8-10 $\mu \mathrm{m}$ wide, and guide cells are in two layers (Zander, in press). D. johansenii differs also in costa narrow and weak in lower part of leaf and gradually broadening in the upper part, excurrent and forming a cylindrical propagulum which is sometimes constricted medially once or twice. The costa of $D$. anserinocapitatus is rather strong and thick in the middle of leaf, gradually narrowing towards the apex, and when running up the apex abruptly broadens into a lanceolate propagulum.

\section{ACKNOWLEDGEMENTS}

We thank Dr. Benito Tan for translation of the Chinese literature. Dr. V. L. Koshkarova and Mr. M. L. Makhlaev kindly provided the literature on geomorphology of Siberia. 


\section{LITERATURE CITED}

[ABRAMOV, I. I. \& A. L. ABRAMOVA] АБРАМОВ, И. И., А. Л. АБРАМОВА 1983. Конспект флоры мхов Монгольской народной республики. - [Mosses of Mongolian Republic] Л., Наука [Leningrad, Nauka], 222.

GAO CHIEN 1996. Flora Bryophytarum Sinicorum. Vol. 2. - Beijing, Science Press. 293

[OTNYUKOVA, T. N.] ОТНЮКОВА, Т. Н. 1995. Материалы к бриофлоре окрестностей г. Красноярска. - [Contribution to the bryoflora of the vicinity of Krasnoyarsk] Тез. докл. Междунар. конф. "Проблемы изучения биологического разнообразия водорослей, грибов и мохообразных Арктики", Санкт-Петербург, 12-16 декабря 1995 [In: Abstr. Intern. Conf. "On the biodiversity of algae, fungi and mosses in Arctic", SanktPeterburg, 12-16 Dec. 1995]: 56-57.

[SAVICZ-LJUBITSKAYA, L. I. \& Z. N. SMIRNOVA] САВИЧ-ЛЮБИЦКАЯ, Л. И., З. Н. СМИРНОВА 1970. Определитель листостебельных мхов CCCP. Верхоплодные мхи. - [Handbook of mosses of USSR. Acrocarpous species] Л., Наука [Leningrad, Nauka] 824.

ZANDER, R. H. Annotated key and phyletic analysis of the moss genus Didymodon in North America Noorth of Mexico. - in press.

ZANDER, R. H. \& W. A. WEBER 1997. Didymodon anserinocapitatus (Musci, Pottiaceae) new to New World. - Bryologist 100(2) 